\title{
Seafood HACCP Regulation: Basic Information for the Florida Seafood Industry'
}

\author{
Razieh Farzad ${ }^{2}$
}

This document is the first in a "Seafood Guide" series, which seeks to help the seafood industry in Florida understand seafood safety regulations.

Seafood Hazard Analysis and Critical Control Point (HACCP) regulation is Title 21 of the Code of Federal Regulation, Part 123 (21 CFR 123), enacted in 1997. This regulation requires entities processing fish and fishery products to implement a preventive food safety plan known as a HACCP plan. It applies to all companies processing fish and fishery products. Seafood importers must comply with HACCP programs equivalent to that for domestic processors (FDA 2021a). Any fish or fisheries products processed or imported in violation of this regulation are considered adulterated and will be subjected to regulatory action.

\section{Definition of Fish, Fisheries Product, and Processing in Seafood HACCP Regulation}

According to the United States Food and Drug Administration (FDA) Fish and Fishery Products Hazards and Controls Guidance (FDA 2021a), fish is defined as fresh or saltwater finfish, crustaceans, other forms of aquatic animal life (including, but not limited to, alligator, frog, aquatic turtle, jellyfish, sea cucumber, and sea urchin, and the roe of such animals) and all mollusks, including land snails (escargot). The rule excludes all aquatic birds and mammals. A fishery product is defined as any food product meant for human consumption in which fish is a characterizing ingredient (e.g., fish sauce, oyster sauce, whitefish spread, crab salad, etc.). Seaweed is not considered a fishery product based on the FDA's definition. The seafood HACCP regulation defines processing as handling, storing, preparing, heading, eviscerating, shucking, freezing, changing into different market forms, manufacturing, preserving, packing, labeling, dockside unloading, or holding fish or fishery products.

\section{The HACCP Regulation does not apply to:}

- Harvesting (i.e., fishing vessels)

- Minimum processing on the fishing vessels, including heading, eviscerating, or freezing on harvest vessels intended solely to hold the fish

- Transporting

- Retail services that directly sell the food products to the consumer

- Aquaculture producers if they are not involved in processing. For example, activities that are integral in harvesting the fish and getting it to market, such as treatment with carbon dioxide, bleeding, washing, and icing of otherwise unprocessed fish, are not considered to be processing. However, the heading, gutting, or packaging of fish (e.g., retail or wholesale packages or cartons)

1. This publication is FSHN22-3, one of a series of the Food Science and Human Nutrition Department, UF/IFAS Extension. Original publication date February 2022. Visit the EDIS website at https://edis.ifas.ufl.edu/ for the currently supported version of this publication.

2. Razieh Farzad, assistant professor and seafood safety Extension specialist, Food Science and Human Nutrition Department and Florida Sea Grant; UF/ IFAS Extension, Gainesville, FL 32611.

The Institute of Food and Agricultural Sciences (IFAS) is an Equal Opportunity Institution authorized to provide research, educational information and other services

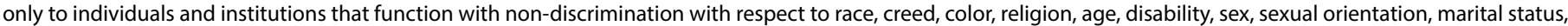

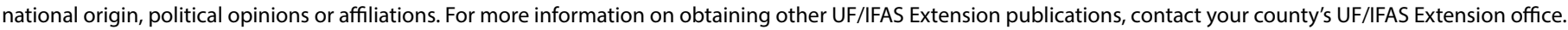
U.S. Department of Agriculture, UF/IFAS Extension Service, University of Florida, IFAS, Florida A \& M University Cooperative Extension Program, and Boards of County Commissioners Cooperating. Andra Johnson, dean for UF/IFAS Extension. 
performed by the aquaculture producer is considered processing and would subject the producer to HACCP regulations (FDA 2018).

\section{Prerequisite Programs}

HACCP is not a stand-alone program. As part of a complete and effective food safety program, seafood processors must also ensure that prerequisite programs are in place before they can successfully implement an effective Seafood HACCP program. Good Manufacturing Practices (GMPs) represent one of these prerequisite programs that apply to all businesses that process, pack, or hold food for human consumption. Formerly 21 CFR 110, the new GMPs under the new Food Safety Modernization Act (FSMA) (21 CFR 117) introduced additional requirements for seafood processors. In addition to training requirements listed in 21 CFR 110, workers (including temporary and seasonal personnel) who are involved in any steps of seafood processing must have the necessary trainings and education for their job duties in order to be considered a "qualified individual." Additionally, they must receive the necessary education in principles of food hygiene and food safety (21 CFR 117.4(b)). Seafood processors must maintain the records of required trainings of those qualified individuals (FDA 2021b). Another prerequisite program is the Sanitation Control Procedures (SCPs). These are also known as Sanitation Standard Operating Procedures (SSOPs). SCPs are procedures put in place to maintain sanitary facilities, equipment, and practices. They are based on the GMPs and help processors outline and describe the goals, methods, and activities that are necessary to address the requirements for the eight key areas of sanitation (21 CFR120.6) (FDA 2022):

\section{Safety of water}

2. Condition and cleanliness of food-contact surfaces

3. Prevention of cross-contamination and cross-contact

4. Maintenance of handwashing, hand-sanitizing, and toilet facilities

5. Protection from adulterants

6. Labeling, storage, and proper use of toxic compounds

7. Employee health conditions

8. Exclusion of pests
Seafood processors are exempt from written sanitation procedure requirements of FSMA's preventive control rule. However, they must keep the records of their monitoring and corrective actions when implanted. The FDA has published detailed guidance (FDA 2021b) on the agency's current thinking related to compliance and exemption of seafood processors from the new FMSA rules.

\section{Preliminary Steps before Starting Your Hazard Analysis and HACCP Plan Development (FDA 2017)}

- Develop a HACCP team: The HACCP team will work together to develop the HACCP plan. The best practice is to include individuals representing different aspects of processing, such as managers, sanitation staff and line workers, or even personnel from marketing and sale.

- Preparing a product description: A product description is crucial for your team and external reviewers or inspectors to clearly understand your product, how it is received, processed, and held, and whom the product will be sold to (i.e., intended use).

- Preparing a process flow chart: The process flow chart is intended to provide a clear and simple description of steps involved in the processing of your fishery products from receipt to distribution. It should include information about nonfishery ingredients (e.g., rice for sushi) that you will use in your product development.

\section{The HACCP Process}

There are two primary components in developing an effective plan for controlling seafood safety hazards. The first is to conduct a hazard analysis, which is meant to identify the hazards associated with your product and process and the critical control points (CCPs). CCPs are the points in the process where hazards must be controlled. Not controlling the hazards at a CCP will lead to foodborne disease. The HACCP regulation does not require a written hazard analysis; however, it is highly recommended to have a written document of your hazard analysis to sustain a successful HACCP plan. Then you must develop a written HACCP plan to prevent, eliminate, or reduce to acceptable levels potential hazards within your facility. After determining CCPs, you should establish critical limits, monitoring procedures, corrective actions, verification processes, and a record-keeping and documentation system. You must have the record of each CCP, the corrective action for that CCP if something goes wrong, and the record of your verification and monitoring procedure. These records must be retained for one year for fresh fish or two years for frozen fish. These 
records help regulators ensure HACCP plans are properly implemented and effectively control potential food safety hazards.

\section{The HACCP Plan Requirement}

Your HACCP plan must be specific to each kind of fishery product and each processing location. It must also be reassessed, signed, and dated yearly (FDA 2021a). Various products (e.g., different species of fish) can be grouped in the HACCP plan if the hazards and controls are the same. All records required by the regulation, including sanitation records, must be retained for one year for refrigerated products and two years for frozen, preserved, or shelf-stable products (FDA 2018).

\section{Seafood HACCP Training}

While no specific training is required, the Seafood HACCP Alliance, led by the Association of Food and Drug Officials, manages a standardized curriculum recognized by US regulatory agencies. To get the seafood HACCP certification, you should complete a two-segment course. The segment one Seafood HACCP course is through Cornell University, and its completion is required to attend the Seafood HACCP segment two training. Course information can be found on the Association of Food and Drug Officials and the Florida Sea Grant Seafood HACCP webpage.

\section{References}

FDA. 2017. "HACCP Principles \& Application Guidelines.” https://www.fda.gov/food/ hazard-analysis-critical-control-point-haccp/ haccp-principles-application-guidelines

FDA. 2018. "Guidance for Industry: Questions and Answers on HACCP Regulation for Fish and Fishery Products." https://www.fda.gov/regulatory-information/search-fdaguidance-documents/guidance-industry-questions-andanswers-haccp-regulation-fish-and-fishery-products

FDA. 2021a. "Fish and Fishery Products Hazards and Controls." Fourth edition. https://www.fda.gov/food/ seafood-guidance-documents-regulatory-information/ fish-and-fishery-products-hazards-and-controls

FDA. 2021b. "Guidance for Industry: Seafood HACCP and the FDA Food Safety Modernization Act." https://www. fda.gov/regulatory-information/search-fda-guidancedocuments/guidance-industry-seafood-haccp-and-fdafood-safety-modernization-act?source=govdelivery\&utm medium=email\&utm_source=govdelivery
FDA. 2022. "CFR—Code of Federal Regulations Title 21." https://www.accessdata.fda.gov/scripts/cdrh/cfdocs/cfcfr/ CFRSearch.cfm?fr $=120.6$ 